\title{
A question of costume Aspects of dress and performance
}

\section{ALLAN THOMAS talks to JANE WOODHALL}

Joseph Lowe notes quite often in his Journal, thathe 'gothome to dinner at three, dressed, and back to the castle at five.' What would he change into?

Evening dress was more formal; instead of the turned down collar for day wear there was a high starched wing collar, which went up into his side whiskers and restricted the movements of the head and neck. In the evening there were also knee breeches for the men, stockings, probably patent leather shoes, and a coat cut-away in front but descending low behind, with a waistcoat and cummerbund : ... all quite fitting and restricting. Day wear was a frock coat, double-breasted reaching almost to the knee, waistcoat and trousers. The general shape of a man for day or evening wear was portly, a pouter pigeon comes to mind - big chests, straight backs, and a narrow waist was part of a manly figure.

The women were terribly tightly boned and corsetted. The low, off the shoulder line also meant that they couldn't raise their arms above a demi-bra. The petticoats (or the hooped skirts that came later) made a great bell shape of the skirt - ten yards could be gathered in at the waist; to the classic 18 inch waist !
You couldn't run away, or run to but you could dance.

What made this $1850-1860$ decade distinctive?

It was the beginning of a new reign, a hopeful time, a new settled period, with an emphasis on the family and on prosperity. For the women, especially, there is the pure, classic line. Doves were a popular image. Women wore tight stays and big soft skirts. They were dressed to show the wealth and position of men, who owned them, I suppose. There was not a blatantly alluring costume; and frivolity was not in fashion - though of

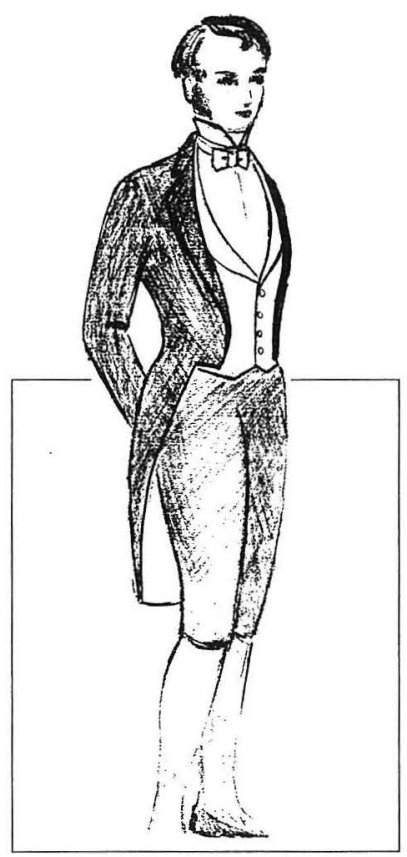

Left: Sketch of Victorian man (Jane Woodhall)

Right: Sketch of Restoration woman (Jane Woodhall)

Opposite: Fancy dress (from Book in Lowe collection)

'Crusader - Suit of chain armour; leg gauntlets, and helmet, with mail coif; surcoat of white cloth. with red cross, flowing white cloak; cross-hilted sword and belt; or a suit of velvet, with cap richly embroidered, with lions on the breast; cloak, sword, etc.' (from Gentlemen's Fancy Dress, Adern Holt, see 'The Lowe Book Collection'.)

Title decoration: Detail of quilting pattern (Jane Woodhall)

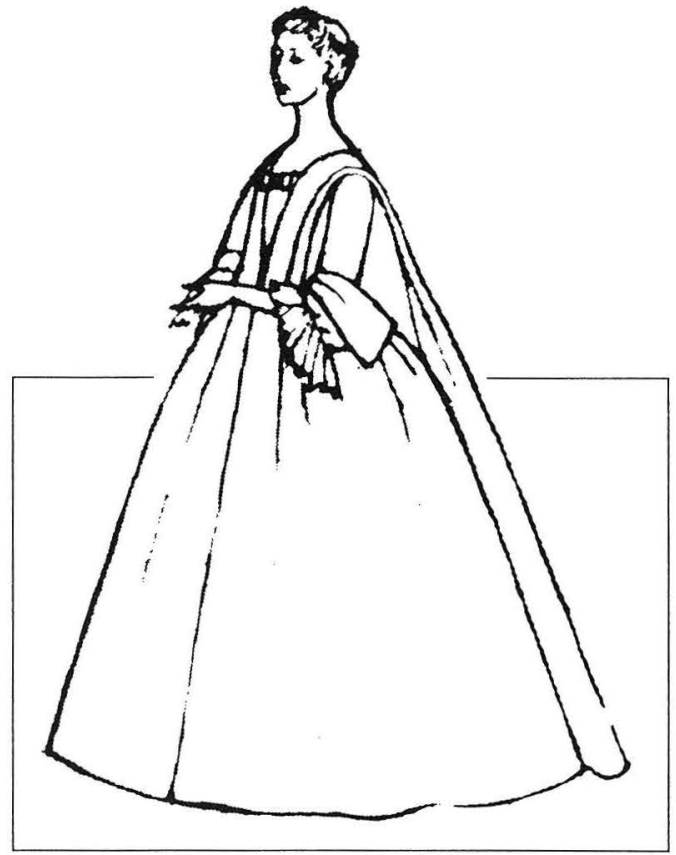


course there was a double-life, a glamorous life, of mistresses and kept women apart from polite society.

How did costume change through the Victorian era?

The waltz had been a daring thing partners touching each other-which Victoria with her love of dance had certainly encouraged. Up until 1855 a woman's skirt was bell shaped, sometimes it had hoops but often a number of stiff and full petticoats. Towards the 1860s the skirt got flatter in the front and the hoop got very large at the back, which changed into the bustle line. And perhaps this was some of the influence of the waltz, and the way partners had to be closer to one another.

After Prince Albert died in 1860 there was mourning for a long period, the Queen didn't dance for years, and the Court dress became heavier and darker.

About 1870 the sewing machine became mass produced - everybody could have one - and suddenly the clothing was very detailed with lots of trimmings, pleated, frilled, bows and flounces; things could be done so much faster. This changed the look of women's clothing. You can see it happen, everything became very fussy for a little while, and then they became sick of it and went plain and smooth again.

The Tomlinson manuscript, more than 100 years earlier, contains dances as staged at Lincoln's Inn Fields Theatre in London. How can we visualize the costume for that dancing?

The stage costume was basically what people outside the theatre were wearing, rather than a fantasy. The difference from the preceding century, the theatre of Inigo Jones, is very clear : the 17th-century stage was a fan- tasy, with huge productions and masque-type costumes. The Restoration theatre on the other hand was more direct, it was aimed at the people of the day, the actors were popular personalities, the costumes were an adaptation of everyday wear. The women were in a dress without a train to manage, in a very similar silhouette to the mid-19th century -

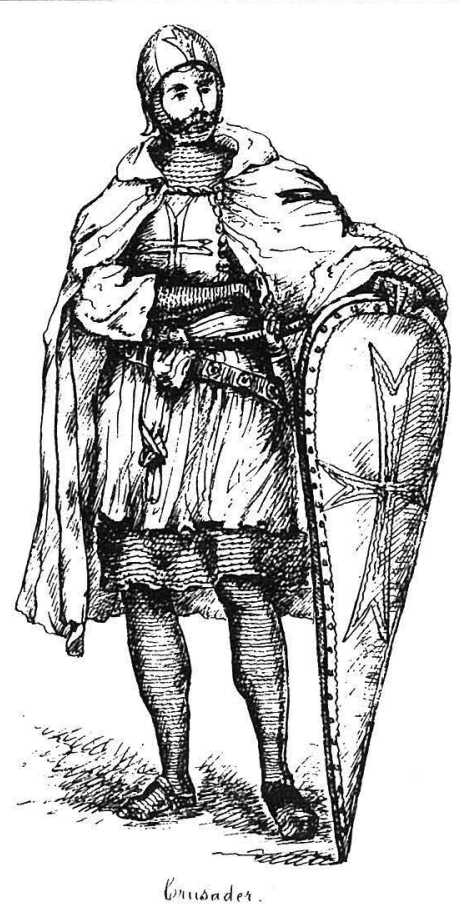

a full skirt just reaching the ground. The hair was not in elaborate headresses but soft and fairly natural. There was an interest in movement rather than in pose or silhouette. And the men were less beribboned - they had wigs, and a full frock coat, knee-breeches, a tasseled cane and were very elegant, but there was less fantasy.

When you were designing the dance costumes of this era did you copy specific dresses of the time?

I wanted a costume that evoked the period, but that didn't take over and dominate the performance, as frills and colours and wigs and beauty spots often do. I wanted it to enhance the dance movement. So I choose a monochrome costume, made of unbleached calico. It needed to represent a wide time span, the first half of the 18th century in which there were a number of fashion changes, so it was rather generalised, And the other requirement in the brief was that it should be able to travel - so I made it without petticoats or hooped skirt. The whole skirt is quilted, to a design of the time (see title decoration), to hold the shape.

18th-century silks were famous, and very valuable, so I sprayed the calico, to give an effect of the sheen, and something of the mellowed, candle-lit look, and people have thought it was embroidered silk !

The other thing that we've encountered in the 19th century, and in New Zealand's history, is fancy dress. The Lowe book collection includes quite elaborate instructions for making historical costumes.

Yes, the instructions are complicated, but the participants still had to look fashionable and beautiful in 19th-century terms; the women are wearing corsets and stays, which give that distinctive shape. They did not abandon those ideals in the 'costume'.

In Jane Austen's Mansfield Park, for instance, the young people in the house were going to put on a play and were dressing up and raiding the attics for old clothes. It was a way of entertaining the young, unmarried. In Jane Eyre too, at a house-party there are plays and charades and they dress up. Obviously it was a game or entertainment of long standing - and I suppose everybody likes to dress-up. 